\title{
Spatial differences in innovation potential of central European regions during post- transformation period
}

\author{
Petr Hlaváček \\ Jan Evangelista Purkynè University in Ústi nad Labem, \\ Ústí nad Labem, Czech Republic \\ Email:petr.blavacek@ujep.cz. \\ Tomáš Siviček \\ Jan Evangelista Purkynè University in Ústi nad Labem, \\ Ústi nad Labem, Czech Republic \\ Email:tomas.sivicek@ujep.cz.
}

\begin{abstract}
The article focuses on mapping the innovation potential of the regions in Czech Republic, Slovakia, and Poland having their own elected institutions, which may influence the development of innovation potential of the regions. The correlation analysis and calculation of the aggregate index were used for comparison of the regions. The research is based on the authors' own construction of the Innovation Potential Index which uses 6 indicators: a) GDP per capita in EUR, b) the share of inhabitants with university degree in population, c) the share of R\&D involved persons per workforce, d) gross fixed capital formation (GFCF) by regions, e) the number of patents and utility models per regions. Better conditions for growing innovation potential can be seen in the metropolitan areas rather than in agricultural and old industrial regions. The main advantage of old industrial regions is that they can improve their innovative potential by transforming the economic potential, which is weak in the peripheral and agrarian regions.
\end{abstract}

Keywords: innovation potential, regions, Czech Republic, Poland, Slovakia.

JEL Classification: O31, R11, R58

\section{INTRODUCTION: INNOVATION POTENTIAL AND A REGION}

Central European regions are more sensitive to economic changes due to post-transformation development processes and thus, growth of innovation potential of these regions is one of their development priorities. The research goal is to evaluate the innovation potential of regions in Czech Republic, Slovakia and Poland. The multifactor observation of innovation potential follows from the fact that the growth of innovation potential is significantly connected not only with economic growth, but also 
with a mechanism of innovation policy and its priorities, what causes complex and differentiated development processes at the regional level as a result.

In general, there is a broad consensus concerning innovation being the source of growth and competitive advantage for companies, regions, and states. Thus, definitions of innovation potential are frequently connected to competitiveness, even as its "backbone element" (Coenen et al., 2015; Nijkamp et al., 2010; Rodionov et al., 2014), but also containing other subsystems (technical scientific; educational; investment; consumer sector) and elements (institutional; investment and financial; organisational and management; consolidate indices).

The studies following the achievements of the national systems of innovations analyse the existence, elements, dynamics, and evaluation of regional systems of innovations. Since, there is economical and political demand for support and stimulation of innovations, the regions prepare their own Regional Innovation Strategies. In contemporary literature focused on innovations in the CEE region, the results suggest that when designing the strategy, the DUI model of innovation (learning by doing, using, interacting) using synthetic knowledge base is more suitable than the STI (science, technology, innovation) model where the process uses analytical knowledge base.

According to Tödtling and Trippl (2005), the innovative environment at the level of regions can be characterised as an evolution process that is conditional upon intensive communication and localisation of innovative stakeholders in the region. The socioeconomic conditions seem to be contextual factors in this regard. Practical implications are related to a broad support of cooperation among actors, development of entrepreneurial culture, or developing nontechnical competencies of companies. Blažek et al. (2012) also points at the positive role of various discussion platforms for stakeholders and regional leadership.

This perspective confirms the important role (positive or negative) of regional authorities and in innovation processes in determining or limiting the innovation potential (Rodriguez-Pose \& Di Cataldo, 2015; Cooke, 1997). In order to help national and regional governments in preparing and implementation of strategies and policies, international institutions provide guidance, expertise, analysis, studies, and other tools (UNDP, 2016; OECD, 2016). The academic and research studies (Riche, 2010; Viturka et al., 2011) are complemented by empirical evidence, usually by private sector analysis (performed by consulting companies for the purposes of private sector itself or also for the public sector - in terms of policies' development).

Pokorný et al. (2008) are more specific in defining the innovation potential "as ability of a region, under certain conditions, to use effectively own resources, to react flexibly to external development impulses, to create and to develop activities with higher value-added, and through that to achieve new, and hieratically higher qualities" (Pokorný et al., 2008). Very valuable inputs from methodological and empirical points of view can be provided by the project INKA (TACR, 2015) on mapping of innovation capacity in Czech Republic.

The Regional Innovation Paradox has been described by Oghton et al. (2002), Klímová and Žítek (2015) as a situation, when regions with lack of innovation have also insufficient absorption capacity for public funding supporting innovation. The work is put in the context of previous studies on regional sys tems of innovation and triple helix and confirms the key importance of regional level for improving innovation performance, although other factors at national and global levels are important as well. The role of regions and regional innovation systems is strengthened by the decentralisation processes, cluster activity, and regionally focused policies like the Cohesion policy (European Commission, 2014; Barca, 2009).

The conclusions of Oghton et al. (2002) suggest more integrated and inclusive approach towards policy design in line with the triple helix concept. The triple helix concept underlines the importance of close cooperation of three elements: government, universities and companies in order to improve innovation performance and competitiveness (Etzkowitz et al., 2003; Etzkowitz \& Leydesdorff, 1997, 2000). However, 
the element of cooperation and interaction is present also in the concepts of learning regions or knowledge regions (Ratajczak \& Weltrowska-Jęch, 2008; Asheim, 1996).

As Asheim (1996) reminds, from the evolutionary point of view, learning regions are a further step in the development from industrial districts defined by Marshallian characteristics and compares it also to Porter's ideas of clustering as a source of competitive advantage. He comments how factors of territory and collaboration influence learning. Learning regions are then seen as a way out of path-dependency trajectory.

In the concept of the regional innovation system, triple helix or theory of learning regions, innovation potential and innovation creation capability is regarded as the key indicator of regional economy growth. The triple helix concept has also practical implications. For instance, in Czech Republic the Operational Programmes, Regional Innovation Strategies are based on this concept. The quadruple helix includes also broader public into the system (Reichert, 2006; Carayannis \& Campbell, 2009) as an important element of knowledge creation and distribution as one of the prerequisite to innovation. In a broader sense, it includes various cultural aspects leading to "innovation culture" (Carayannis \& Campbell, 2011) necessary for promoting knowledge-based economy and knowledge society and they further develop the concept into quintuple helix taking into consideration also the "natural environment".

At the level of the European Union, the topic of innovation is among priorities as well. It is directly related to its ambitious strategy "Europe 2020" - as one of the seven flagship initiatives called "Innovation Union". The goal of this initiative is to create suitable environment for innovations improving quality of live, increasing competitiveness and creating more jobs by top quality research, removing barriers to innovation and supporting public-private cooperation. For fostering territorial and social cohesion or "catching up" in competitiveness and innovation of the lagging behind regions and for better efficiency and coordination of national and European tools and sources used, the European Union provides guidance for research and innovation strategies for smart specialisation (RIS3). The national level RIS3 strategy with regional annexes is usually accompanied by a Regional Innovation Strategy, which is usually a broader strategic document.

The article aims at reviewing the innovation potential of the regions in Czech Republic, Slovakia and Poland with their own elected institutions, which may influence the development of innovation potential of these regions. The article focuses on the analysis of innovations within the development of innovation environment in the regional dimension and aims to ascertain the differences between the self-governed regions in Central Europe. Therefore, data from the self-governed units is monitored at the NUTS III level for Czech Republic and Slovakia, and the NUTS II for Poland, which is added value for the article because the research of self-governed regions is not frequently published for international comparison due to poor data accessibility from NUTS III. To monitor the potential of the regional innovation environment, various types of indicators and data should be reviewed and therefore, the search will monitor the selected characteristics from the macroeconomic data, regional labour markets, and R\&D used for determination of the Innovation Potential Index referring to the data from 2010 to 2012. Our sources of information include the Eurostat, Central Statistical Office of Poland, Czech Statistical office, Statistical office of the Slovak Republic.

\section{METHODS FOR MEASURING INNOVATION POTENTIAL}

Definition of the relevant methodology for evaluation of the data sets for different types of indicators is needed in the analysis of the innovation potential. The regional innovation potential can be referred to as an ability of a region to effectively use internal resources, to respond flexibly to the external development trends and competition, to develop the activities and products having higher added value, and to form the 
regional environment assisting in the development of the innovations. According to Andersson and Karlsonn (2004) the national innovation systems are defined by the state and governmental policies, the regional innovation systems specific for each region and their regional policy, and the innovation systems defined by knowledge and technologies, and networks in production chains. Hence, the quantitative review of the innovation potential of the regions required capturing of the specific factors that when combined cocreate and form the innovative environment and the innovation potential of the region to a certain extent.

Among the tools provided by the initiative "Innovation Union" is an "Innovation Union Scoreboard" for measuring a progress in innovation even for every member country, which should be helpful for policy design, making, implementation and evaluation. It uses a composite index "Summary Innovation Index" based on 25 indicators of 3 main types (Enablers, Firm Activities, Outputs) covering 8 dimensions for measuring innovation performance. The Enablers cover availability of Human Resources, attractiveness of research system and availability of finances. The Firm activities cover firm investment $(R \& D$, non $R \& D$ innovation); linkage and entrepreneurship (in-house or collaborative innovation and publications), intellectual assets (e.g. patent applications, trademarks, design). Finally, Outputs cover Innovators (SMEs with process, product, marketing and organizational innovations; employment in fast-growing sectors) and economic effects (e.g. employment, export of knowledge intensive products and services, income from IPR from abroad).

This index allows dividing countries into four groups: Innovation Leaders, Innovation Followers, Moderate Innovators, and Modest Innovators; based on the average performance. All three countries - the Czech Republic, Slovakia and Poland are among "moderate innovators" slightly under the EU average. (European Commission, 2015) Besides this index, the European Union conducts and prepares several other analyses surveys like: Foresights, Community Innovation Survey, Innobarometer, Business Innovation Observatory, Regional Innovation Monitor plus, or Regional Innovation Scoreboard. Counterfactual impact evaluations are used in order to measure efficiency of policy and sources.

The Regional Innovation Scoreboard provides information on innovation performance at regional level. Using the same methodology, but measuring only 11 indicators due to lack of regional data, it also divides regions (NUTS II.) into four groups just as the Innovation Union Scoreboard. For instance, all the regions in the Czech Republic are classified as Moderate Innovators, but in Poland, there are regions classified as Moderate Innovators as well as Modest Innovators, and in Slovakia there is also a third group of Innovation Follower. The study suggests that regions with positive attitude to new things, lifelong learning, and with public funds supporting innovations are more successful. In the context of EU funding, there are only a few regions able to use even Framework programmes (15.6 \%), some focus on supporting services $(6.1 \%)$, some on technological and research activities $(3.7 \%)$ and some on both areas $(3.7 \%)$, when using structural funds, while the vast majority of regions are low absorbers $(71 \%)$, which supports the argument about the Regional Innovation Paradox (EC, RIS 2014).

The research has been applied at the level of regions having their regional government because each region stimulates its development innovation policy, and uses its measures and instruments to directly influence the growth of the innovation potential in the region. Therefore, the research was applied at the regional levels (NUTS III.) in the Czech Republic and Slovakia, and voivodeships (NUTS II) in Poland. On the other hand, combination of the research and the regional government level resulted in fact that NUTS II. and NUTS III. level data had to be used in the research as well because the link of the territory to the regional government has higher priority that the size category of the NUTS territorial classification.

To analyze the innovation potential of the regions, for research is constructed own the Innovation Potential Index, this index is based on similar Regional Competitiveness Index (RCI) applied by the European Commission Directorate for the competitiveness analysis at the level of the NUTS II regions. 
The RCI has been designed based on the set of selected indicators from the fields of infrastructure, human resources, and production environment, which are standardized and subsequently summed to form the resulting RCI. The methodology for calculation of the Innovation Potential Index also uses some indicators used for calculation of this index, and some other indicators relevant to mapping of the regional innovation potential are added. The method for calculation of the Innovation Potential Index used in this article uses 6 indicators listed in Table 1.

For the purpose of evaluation of the development trajectories, the development of GDP per capita in the period of question provides rather representative view on monitoring of the economic development of the region. The first evaluation criterion is the development level of the regional economy represented by the gross domestic product per capita (in PPS). Another indicator is the average volume of the fixed capital between 2010 and 2012 that points out to the investment activities in the regions. Higher investment activity also includes the investments in procurement of the new technologies and equipment that increase working productivity and contribute to the growth of the innovation potential of the region. The indicator of share of inhabitants in the region with full tertiary education between 2010 and 2012 represents the conditions prevailing on the labour market, which points out to the regional potential of the knowledge economy and innovation environment. Data about share of $R \& D$ staff in the workforce make the innovation potential complete in the field of the workforce. The last indicator for calculation of the Innovation Potential Index is the number of patents and utility models between 2010 and 2012 converted per workforce.

Table 1

The indicators used for calculation of the Innovation Potential Index ( $I_{I P A}$ and $\left.I_{I P B}\right)$

\begin{tabular}{|l|l|l|l|}
\hline \multicolumn{1}{|c|}{ symbol } & \multicolumn{1}{|c|}{ indicator } & \multicolumn{1}{c|}{ years } & \multicolumn{1}{c|}{ source } \\
\hline I. - GDP_EA & $\begin{array}{l}\text { gross domestic product per } \\
\text { capita (EUR) }\end{array}$ & -2012 and 1214 & Eurostat \\
\hline II. - UNI_POP & $\begin{array}{l}\text { share of population with } \\
\text { university degree (in \%) }\end{array}$ & $\begin{array}{l}- \text { average value } \\
(11 / 12 \text { and 13/14) }\end{array}$ & $\begin{array}{l}\text { Eurostat, statistical office } \\
\text { from CZ, PL, SVK }\end{array}$ \\
\hline III. - RD_EA & $\begin{array}{l}\text { share of R\&D personnel on } \\
\text { labour force by region (in \%) })\end{array}$ & $\begin{array}{l}\text {-average value } \\
(11 / 12 \text { and 13/14) }\end{array}$ & $\begin{array}{l}\text { Eurostat, statistical office } \\
\text { from CZ, PL, SVK }\end{array}$ \\
\hline IV. - FIX_EA & $\begin{array}{l}\text { gross fixed capital formation } \\
\text { (GFCF) per employee }\end{array}$ & -2012 and 1214 & $\begin{array}{l}\text { Eurostat, statistical office } \\
\text { from CZ, PL, SVK }\end{array}$ \\
\hline V. - GVA_EA & $\begin{array}{l}\text { gross value added per } \\
\text { employee }\end{array}$ & $\begin{array}{l}- \text { average value } \\
(11 / 12 \text { and 13/14) }\end{array}$ & $\begin{array}{l}\text { Eurostat, statistical office } \\
\text { from CZ, PL, SVK }\end{array}$ \\
\hline VI.- PAT_EA & Patents per employee & $\begin{array}{l}- \text { average value } \\
(11 / 12 \text { and 13/14) }\end{array}$ & $\begin{array}{l}\text { Eurostat, statistical office } \\
\text { from CZ, PL, SVK }\end{array}$ \\
\hline
\end{tabular}

Source: Authors own calculations

The group of indicators focused on the analysis of the regional labour market, used the following data from the regional level in the Czech Republic, Poland and Slovakia:

- GDP_EA - represents gross domestic product per capita that provides a representative insight to the economic potential of the region.

- UNI_POP - share of population with university degree (in percentage). The character of the economic situation in the region but also indicates the educational quality of the population.

- RD_EA - share of R\&D employee on labour force (in percentage).

- FIX_EA - gross fixed capital formation per capita refers to overall investment activity in the region.

- GVA_EA- gross value added per employee shows productivity of economies 
- PAT_EA - number of patents in the year 2010-2012 per employee.

The analysis stems from the research goal and evaluates data that represents the selected areas, and has been monitored statistically over the long term at the same time. The selected research data has some specific limitations resulting from its aggregation for the regions, e.g. employment in R\&D also includes branches not focused on the development of the innovations. However, detailed information about R\&D outlays is not available and therefore, aggregated data needs to be used. Csank and Žižalová (2009) note in the analyses of the innovation potential that the inputs to the innovation process, which often result from cooperation with various companies and research institutions, are measured. Research is often the result of multidisciplinary and interregional networks; research results and patent applications may be the result of wider interregional and international participation. This indicators shows the capability of the regional environment to adapt to ongoing social, economic and innovation processes, to create new jobs or to find opportunities on the regional labour markets. The Innovation Potential Index $\left(I_{I P A}\right)$ assessed the regional innovation environment wherein the indices were calculated according to the following formulas:

a) standard deviation $\sigma(x)$

$$
\sigma(x)=\sqrt{\sum_{i=1}^{\mathrm{N}} \frac{1}{N}\left(\mathrm{x}_{i}-\mu_{N}\right)^{2}},
$$

$\mathrm{x}$ - represents monitored indicator,

$\mathrm{N}$ - region,

$\mu$ - aritmetic value of monitored indicator for group of regions.

b) Innovation Potential Index (var A.- $\left.I_{I P A}\right)$

$$
\begin{gathered}
I_{I P A(1-N)}=\left[\left(I_{(1-N)-} \mu I_{(1-N)}\right) / \sigma_{I}+\left[\left(I I_{(1-N)-} \mu I I_{(1-N)}\right) / \sigma_{I I}+\left(I I I_{(1-N)}-\mu I I I_{(1-N)}\right) / \sigma_{I I I}+\right.\right. \\
{\left[\left(I V_{(1-N)}-\mu I V_{(1-N)}\right) / \sigma_{I V}+\left[\left(V_{(1-N)}-\mu V_{(1-N)}\right) / \sigma_{V}+\left(V I_{(1-N)}-\mu V I_{(1-N)}\right) / \sigma_{V I}\right] / 6 .\right.}
\end{gathered}
$$

$I_{I P A(1-N)}$ is index, which shows formula for calculating of value for years 2012 and $2014\left(I_{\text {IPA2012(1-N) }}\right.$ and $\left.\mathrm{I}_{\mathrm{IPA} 2014(1-\mathrm{N})}\right)$. First, individual indicators were calculated together with the standard deviation for each regional indicator from the data for the regions. The calculated values were also used for standardisation of the data file and the comparison of the calculated dimensionless values. The calculated indicators for each region have either positive or negative values, where the positive value means an above-average value, and a negative value means a less-than-average value when compared to the mean indicator value for the regions in question. The values are designed so that the sum of the index region values for an indicator is always zero, i.e. $\sum I_{I P 2012(1-\mathrm{N})}=0$ and also $\Sigma I_{I P 2012(1-\mathrm{N})}=0$ and $\sum I_{I P 2014(1-\mathrm{N})}=\mu I_{I P 2014(1-\mathrm{N})}=0$.

c) Innovation Potential Index (var B.- $\left.I_{I P B}\right)$

$N$ - region,

$$
I_{I P B(1-N)}=\sum_{X=I}^{\mathrm{VI}} x_{(1-N)} / \max x_{(1-N)} * 100
$$

$x$ - represents monitored indicator.

The selected indicators are of a macroeconomic nature, it can be assumed considering their complete information value, that they characterize the economic and innovation dimensions of the regions. Data from 
Eurostat and to a lesser extent data from databases of the national statistical offices in Poland, Czech Republic, and Slovakia were used. The analysis works on data from years 2012 and 2014.

The calculated Innovation Potential Index $\left(I_{I P B}\right)$ has been expressed in per cents. The absolute values of the indicators were first standardized in the 0 to $100 \%$ interval, wherein maximum value was used for each indicator as a benchmark. In the next step the \% deviation from maximum value was calculated as found in the group of Czech, Polish, and Slovak regions. The last step summarized the values in each area for each region, and their final average value, based on six monitored indicators in formula (2), was calculated to represent the resulting Innovation Potential Index.

Table 2

Standardized regional indicators $I_{I P A 2012}$ and $I_{I P A 2014}$

\begin{tabular}{|c|c|c|c|c|c|c|c|}
\hline region & $I_{I P A 2012}$ & $I_{I P A 2014}$ & $\begin{array}{c}\text { change } \\
14-12 \\
\end{array}$ & region & $I_{I P A 2012}$ & IIPA2014 & $\begin{array}{c}\text { change } \\
14-12 \\
\end{array}$ \\
\hline Praha (CZ) & 1,95 & 2,44 & 0,48 & Banskobystrický (SK) & $-0,39$ & 0,51 & 0,90 \\
\hline Středočeský (CZ) & 0,21 & $-0,14$ & $-0,34$ & Prešovský (SK) & $-0,19$ & 0,22 & 0,41 \\
\hline Jihočeský (CZ) & $-0,05$ & $-0,25$ & $-0,20$ & Košický (SK) & $-0,19$ & 0,64 & 0,83 \\
\hline Plzeňský (CZ) & 0,08 & $-0,21$ & $-0,29$ & Lódzkie (PL) & $-0,18$ & $-0,42$ & $-0,24$ \\
\hline Karlovarský (CZ) & 0,39 & $-0,76$ & $-1,15$ & Mazowieckie (PL) & 0,83 & 0,43 & $-0,41$ \\
\hline Ústecký (CZ) & 0,21 & $-0,48$ & $-0,69$ & Malopolskie (PL) & 0,13 & $-0,13$ & $-0,26$ \\
\hline Liberecký (CZ) & $-0,71$ & $-0,15$ & 0,56 & Slaskie (PL) & $-0,10$ & $-0,24$ & $-0,14$ \\
\hline Královéhradecký (CZ) & 0,11 & $-0,29$ & $-0,40$ & Lubelskie (PL) & $-0,51$ & $-0,50$ & 0,01 \\
\hline Pardubický (CZ) & 0,30 & $-0,10$ & $-0,40$ & Podkarpackie (PL) & $-0,51$ & $-0,36$ & 0,16 \\
\hline Vysočina (CZ) & 0,05 & $-0,44$ & $-0,49$ & Swietokrzyskie (PL) & $-0,54$ & $-0,53$ & 0,00 \\
\hline Jihomoravský (CZ) & 0,70 & 0,41 & $-0,29$ & Podlaskie (PL) & $-0,46$ & $-0,35$ & 0,10 \\
\hline Olomoucký (CZ) & $-0,09$ & $-0,30$ & $-0,21$ & Wielkopolskie (PL) & $-0,12$ & $-0,22$ & $-0,09$ \\
\hline Zlínský (CZ) & 0,03 & $-0,23$ & $-0,25$ & $\begin{array}{l}\text { Zachodniopomorskie } \\
(\mathrm{PL})\end{array}$ & $-0,19$ & $-0,18$ & 0,01 \\
\hline Moravskoslezský (CZ) & $-0,06$ & $-0,25$ & $-0,19$ & Lubuskie (PL) & $-0,28$ & $-0,46$ & $-0,19$ \\
\hline Bratislavský (SK) & 2,04 & 2,37 & 0,33 & Dolnoslaskie (PL) & 0,14 & 0,00 & $-0,14$ \\
\hline Trnavský (SK) & 0,02 & 0,43 & 0,42 & Opolskie (PL) & $-0,41$ & $-0,40$ & 0,01 \\
\hline Trenčiansky (SK) & $-0,33$ & 0,05 & 0,38 & $\begin{array}{l}\text { Kujawsko - Pomor. } \\
(\mathrm{PL})\end{array}$ & $-0,41$ & $-0,50$ & $-0,09$ \\
\hline Nitriansky (SK) & $-0,32$ & 0,84 & 1,15 & $\begin{array}{l}\text { Warminsko } \\
\text { Mazur.(PL) }\end{array}$ & $-0,55$ & $-0,49$ & 0,06 \\
\hline \multirow[t]{3}{*}{ Žilinský (SK) } & $-0,49$ & 0,21 & 0,71 & Pomorskie (PL) & $-0,01$ & $-0,16$ & $-0,15$ \\
\hline & & & & mean & 0,00 & 0,00 & 0,00 \\
\hline & & & & standard deviation & 0,57 & 0,67 & \\
\hline
\end{tabular}

Source: Authors own calculations

\section{RESULTS OF THE INNOVATION POTENTIAL INDEX ANALYSIS}

The values of the Innovation Potential Index report comparatively significant differences among Czech, Slovak, and Polish regions. Considering the complex review of the indicators, the Czech regions followed by the Slovak and Polish ones achieve generally higher innovation potential in 2012. As shown in 
Table 2, the development before 2014 was associated with various growth changes. The overall assessment clearly shows slower pace in the growth of the indicators for the Czech regions, which lagged behind the Polish regions. On the contrary, above-average growth in the Slovak regions has been recorded because these regions adapted best to the economic environment in the post-crisis period. From the point of view of the development of various groups of regions, the most innovation developed regions are those with the capital cities and major metropolitan areas, which do not undergo significant structural changes as seen in Figure 1. The rural and peripheral regions report weaker innovative potential, which is also reflected by the differences in the west-east gradient. Fedirko (2014) also confirms the context between the economic potential and the innovative potential of the regions. The research of the innovative potential of regions from other authors, e.g. research of the Visegrad countries (e.g. Kozun-Cieslak, 2016) points to the other factors that impact their potential, such as historical circumstances and geographical advantages. The political aspects have a specific role, while the approaches of the regional and city governments in support of economic development are also different (Sucháček, 2013) where the regions - according to his findings - are more active and have a higher economic potential to influence the changes in the localization of companies than the city governments. According to the research of the innovation potential by Hoope and Winter (2015), similar intranational differences could also be found in the area of transport; in addition to the metropolitan areas, Lower Silesia in Poland and Kuyavian-Pomeranian have higher innovative potential. In Slovakia, the east-west polarity is strongly reflected, and as far as Czech Republic is concerned, stronger positions are occupied by Southern Moravia and the northern part of the country in addition to the Prague metropolitan area. The existence of the said differences must not necessarily mean the growth of regional divergence; according to Zdražil and Applová (2016) it could generally be said that the convergence is conditional and occurs in the Czech, Polish, and Slovak regions.
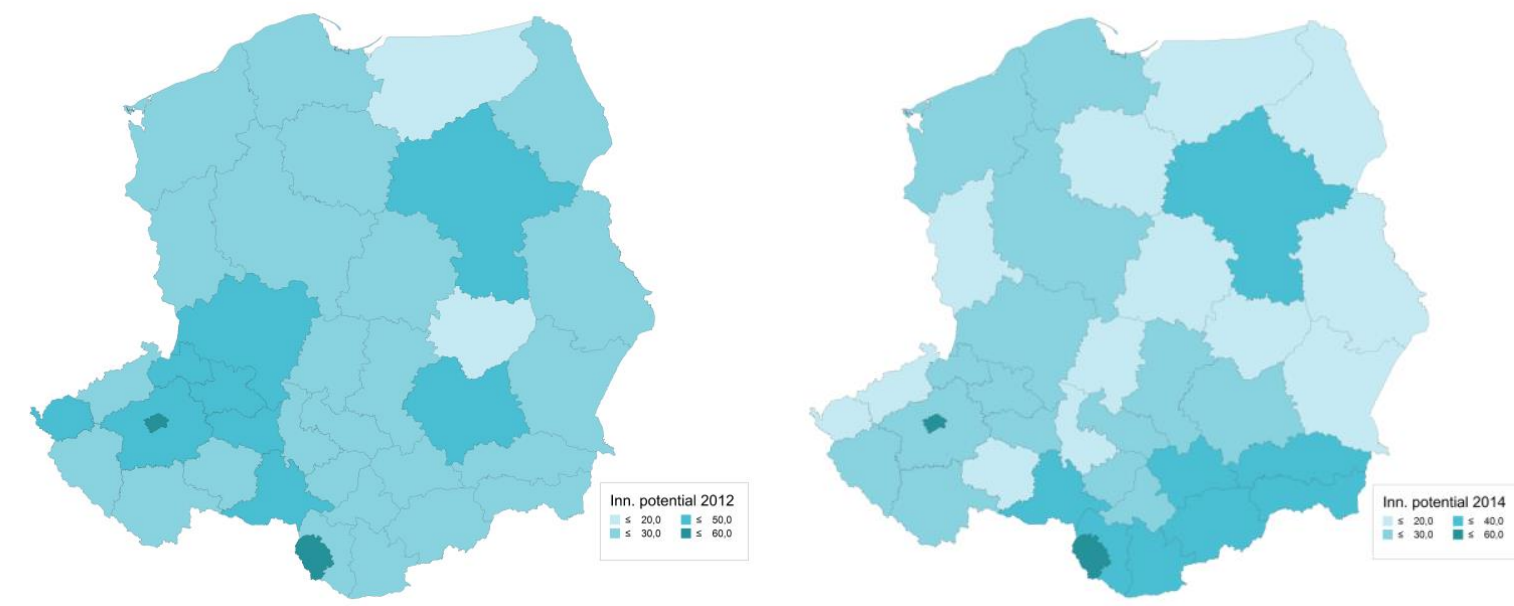

Figure 1. Changes of the Innovation Potential Index $I_{I P B 2012}$ and $I_{I P B 2014}$ in the years 2012 and 2014 Source: own calculation

The advantages of the capital cities is substantially higher share of R\&D workforce, and the developed network of colleges, universities, and $\mathrm{R} \& \mathrm{D}$ facilities, as well as higher investments level per workforce compared to the other regions. Southern Moravia Region having higher level of patents and fixed capital converted to economically active inhabitants sums up this category; it achieves substantially higher values compared to the other regions in both indicators. 
In case of Slovak regions and of Polish ones to a certain extent, the factor of the geographic location of the territory in the East - West axis is reflected significantly in the innovation potential, where the innovation potential increases westwards. For the Czech regions, this factor is less significant compared to Poland and Slovakia. Although importance of the settlement structure and metropolitan areas are reflected in ranking of the regions and the amount of the innovation potential, the administrative definition of the units of the regional governments in case of larger regions statistically reduces the potential of the regional centres.

The regional data was further analyzed by correlation thereof in order to monitor the dependence level among the indicators used in the calculation of the Innovation Potential Index. The data set from among the selected indicators and the innovation potential was compared with other innovative factors while the $\mathrm{R} \& \mathrm{D}$ outlays were also monitored. The use of the indicator for the $\mathrm{R} \& \mathrm{D}$ outlays per each employee is based on the endogenous growth model by Romer (1994), which is expressed as $Y=f(R, K, L)$, where the R\&D outlays are an endogenous growth component that determines the total product quality. The results of the correlation analysis among the indicators are shown in Table 3 where annual average from 2010-2012 is calculated to remove annual sudden changes.

Table 3

The correlation dependence of selected indicators of Czech, Polish, and Slovak regions between 2012 and 2012

\begin{tabular}{|c|c|c|c|c|c|c|c|}
\hline & & GDP_EA12 & UNI_POP12 & RD_EA12 & FIX_EA12 & 2GVA_EA12 & PAT_EA12 \\
\hline \multirow{2}{*}{ GDP_EA12 } & Pearson Correlation & 1 & .039 & $.399^{*}$ &, $421^{* *}$ &, 432 & ,316 \\
\hline & Sig. (2-tailed) & & .816 & .013 & ,008 & ,007 & ,053 \\
\hline \multirow{2}{*}{ UNI_POP12 } & Pearson Correlation & .039 & 1 & .285 & 225 &,- 081 &,- 095 \\
\hline & Sig. (2-tailed) & .816 & & .083 & ,175 & ,631 & ,569 \\
\hline \multirow{2}{*}{ RD_EA12 } & Pearson Correlation & $.399^{*}$ & .285 & 1 &, $870^{* *}$ & ,748* & ,109 \\
\hline & Sig. (2-tailed) & .013 & .083 & &, 000 & 000 & ,516 \\
\hline \multirow{2}{*}{ FIX_EA12 } & Pearson Correlation & $.421^{* *}$ & .225 & $.870^{* *}$ & 1 & ,762** & ,099 \\
\hline & Sig. (2-tailed) & .008 & .175 & .000 & & ,000 & ,555 \\
\hline \multirow{2}{*}{ GVA_EA12 } & Pearson Correlation & $.432^{* *}$ & -.081 & $.748^{* *}$ &, $762^{* *}$ & $1^{* *}$ &, 197 \\
\hline & Sig. (2-tailed) & .007 & .631 & .000 &, 000 & & 237 \\
\hline \multirow{2}{*}{ PAT_EA12 } & Pearson Correlation & .316 & -.095 & .109 & ,099 & ,197 & 1 \\
\hline & Sig. (2-tailed) & .053 & .569 & .516 & ,555 & 237 & \\
\hline & & GDP_EA14 & UNI_POP14 & RD_EA14 & FIX_EA14 & 4GVA_EA14 & PAT_EA14 \\
\hline \multirow{2}{*}{ GDP_EA14 } & Pearson Correlation & 1 & $416^{* *}$ &, $859^{* *}$ & ,943** & ,587 & $260^{* *}$ \\
\hline & Sig. (2-tailed) & & ,009 & ,000 & ,000 & 000 & ,115 \\
\hline \multirow{2}{*}{ UNI_POP14 } & Pearson Correlation & $416^{* *}$ & 1 & ,404* & ,326* &, $135^{* *}$ &,- 114 \\
\hline & Sig. (2-tailed) & ,009 & & ,012 &, 046 & ,419 & ,494 \\
\hline \multirow{2}{*}{ RD_EA14 } & Pearson Correlation &, $859^{* *}$ & ,404* & 1 &, $814^{* *}$ &, $711^{* *}$ & ,521* \\
\hline & Sig. (2-tailed) &, 000 &, 012 & &, 000 & 000 & ,001 \\
\hline \multirow{2}{*}{ FIX_EA14 } & Pearson Correlation & ,943** & $326^{*}$ &, $814^{* *}$ & 1 &, $481^{* *}$ & $214^{*}$ \\
\hline & Sig. (2-tailed) & ,000 & ,046 & 000 & & ,002 & ,198 \\
\hline \multirow{2}{*}{ GVA_EA14 } & Pearson Correlation & $587^{* *}$ & ,135 & ,711 ** & $481^{* *}$ & $1^{* *}$ & ,652 \\
\hline & Sig. (2-tailed) & 000 & ,419 & ,000 & ,002 & &, 000 \\
\hline \multirow{2}{*}{ PAT_EA14 } & Pearson Correlation & 260 &,- 114 &, $521^{* *}$ & ,214 & ,652 & 1 \\
\hline & Sig. (2-tailed) & ,115 & ,494 & ,001 & ,198 & ,000 & \\
\hline
\end{tabular}

* Correlation is significant at the 0.05 level (2-tailed).

**. Correlation is significant at the 0.01 level (2-tailed).

Source: own calculation 
The data indicates a statistically significant dependency at $99 \%$ reliability level between the macroeconomic indicators, in particular between the GDP level, investment, and innovation factors. Higher investments are reported in the regions with higher level of the gross domestic product; statistically most significant dependence with 99\% reliability level was demonstrated between the gross domestic product level converted per capita and the volume of investments per workforce. Also significant is the direct dependence between the investment levels per economically active person and other macroeconomic indicators. More patents are applied to where the companies make higher investments and regions have higher level of GDP. Inversely, the dependence between the unemployment rate and the number of patents and education of the population demonstrated as well, where the correlation between the level of the regional HDP and most of the monitored indicators increases between 2012 and 2014 while the more developed regions report higher values of the other indicators in 2014. A similar development can also be seen in the field of human resources in R\&D, investments, and growth of added value.

However, available data demonstrate higher share of $R \& D$ workforce in the regions of the metropolitan character, particularly those with capital cities. On the contrary, the regions of the nonmetropolitan and of rather rural nature have lower share of this workforce and have lower economic and innovative potential.

\section{CONCLUSION}

The article aimed at reviewing of the innovation potential of the regions in the Czech Republic, Slovakia, and Poland having their own elected regional institutions, which may influence the growth of the innovation potential of the regions. From the point of complex review of the differences among the regions, the Czech regions have higher innovation potential in average followed by the Slovak and Polish regions. Better conditions for growing innovation potential can be seen rather in the metropolitan areas than the regions focused more on agriculture and the old industrial regions.

The key benefits of the analysis include the finding that the critically judged category of the old industrial regions reports rather good conditions for the development of the innovative environment with respect to the future perspective. Despite the old industrial regions being characterised by a range of social and economic problems such as a high unemployment level, obsolete industry, a focus on mining, and an impaired environment, the regions have a rather high growth potential. The advantages of the old industrial regions, such as Moravia-Silesia Region in Czech Republic or Silesian Voivodeship in Poland is that they may transform the economic potential which is very weak in the peripheral and agrarian regions (Lubelskie in Poland or Prešov Region in Slovakia).

A disadvantage of the agrarian and peripheral regions is the low concentration of resources in the longterm run such as capital, investment, human resources, and traffic and technical infrastructure to a certain extent. The insufficiency of the resources is a heavily limiting factor, which has a negative impact on their future development. The relationship among the applied indicators was the object of the correlation analysis aiming at finding out the dependence of the reviewed regions. The regions with higher GDP per capita and investments per workforce show also better conditions for growing innovation potential. Many regionally specific factors having their impact on the innovation environment of the region and growing innovation potential can be defined in the review of the regional differentiation of the innovation potential. An important factor is educated and flexible workforce employable in companies from the growing sectors being localized in the regions.

Central support from the public resources for further growth of the innovation potential should be aimed at the firms (Streimikiene, 2014; Zumbusch \& Scherer, 2012; Hlaváček, et al. 2015), which make up 
the main segment with the innovation potential on the basis of the principal sectors of the regional economy, hand in hand with motivation of the out-of-regional and winning of the new investors bringing higher added value, and developing in the innovative business with the use of the modern technologies and services. The geographical location of the region in combination with good transport connections to the Western markets creates good conditions for growing innovation potential.

The R\&D policy in these countries also has a regional dimension, which can be seen as an endogenous instrument for the innovative growth of the regions. A feature is the change from the top-down approach to the bottom-up approach consisting in the support of independently organized networks of participating companies, public sector, and R\&D. The regional innovation strategies often aims at basing on the endogenous factors of the region, innovatively and potentially dominant sectors in the region complemented by the public support to the companies expressing high innovative potential. The topics aimed at the analysis of the national and regional level of the innovation policies and their benefits for development of the intersectorial cooperation of local companies, impact of the innovative policies on the growth of the regional innovation potential, or statistic expansion of the set of further relevant indicators with direct link to the description of the innovation potential of the regional economies are very inspirational for the future research.

The expansion of the number of indicators and data, which will map the innovation environment of the regions, could be recommended for further research of the innovation potential. Although the research data used in the article is not able to fully assess the quality and complexity of the innovation potential of the regions, the research results are a valuable source of information for mapping the innovation potential of the regions and setting up innovation and regional policy tools.

\section{ACKNOWLEDGEMENTS}

This work was supported by the Internal Grant 2016/2017 Agency of Jan Evangelista Purkyně University in Ústí nad Labem in the Czech Republic.

\section{REFERENCES}

Andersson, M., \& Karlsson, Ch. (2004). Regional Innovation Systems in Small \& Medium-Sized Regions. CESIS, Electronic Working Paper Series. Retrieved from https://static.sys.kth.se/itm/wp/cesis/cesiswp10.pdf, referred on 14/02/2017.

Asheim, B. R. T. (1996). Industrial districts as 'learning regions': a condition for prosperity. European planning studies, 4(4), 379-400.

Asheim, B. T., Boschma, R., \& Cooke, P. (2011). Constructing regional advantage: Platform policies based on related variety and differentiated knowledge bases. Regional studies, 45(7), 893-904.

Barca, F. (2009). An Agenda for a Reformed Cohesion Policy: A Place-Based Approach to Meeting European Union Challenges and Expectations. Independent Report, prepared at the request of the European Commissioner for Regional Policy, European Commission, Brussels.

Barca, F., McCann, P., \& Rodríguez-Pose, A. (2012). The case for regional development intervention: place-based versus place-neutral approaches. Journal of regional science, 52(1), 134-152.

Blažek, J., Žížalová, P., Rumpel, P., Skokan, K., \& Chládek, P. (2013). Emerging regional innovation stra tegies in Central Europe: institutions and regional leadership in generating strategic outcomes. European Urban and Regional Studies, 20(2), 275-294.

Boschma, R. (2014). Constructing regional advantage and smart specialisation: comparison of two European policy concepts. Scienze Regionali, 1(1), 51-68. 
Carayannis, E. G., \& Campbell, D. F. (2009). 'Mode 3'and'Quadruple Helix': toward a 21st century fractal innovation ecosystem. International journal of technology management, 46(3-4), 201-234.

Carayannis, E. G., \& Campbell, D. F. (2011). Open innovation diplomacy and a 21 st century fractal research, education and innovation (FREIE) ecosystem: building on the quadruple and quintuple helix innovation concepts and the "mode 3" knowledge production system. Journal of the Knowledge Economy, 2(3), 327.

Coenen, L., Moodysson, J., \& Martin, H. (2015). Path renewal in old industrial regions: Possibilities and limitations for regional innovation policy. Regional Studies, 49(5), 850-865.

Cooke, P., Uranga, M. G., \& Etxebarria, G. (1997). Regional innovation systems: Institutional and organisational dimensions. Research policy, 26(4-5), 475-491.

Žížalová, P., \& Csank, P. (2009). Jsou výzkum, vývoj a inovace klíčové procesy (nerovnoměrného) regionálního rozvoje. Geografie, 114(1), 21-36.

Etzkowitz, H., \& Carvalho de Mello, J. M. (2004). The rise of a triple helix culture: Innovation in Brazilian economic and social development. International Journal of Technology Management \& Sustainable Development, 2(3), 159-171.

Etzkowitz, H., \& Leydesdorff, L. (2000). The dynamics of innovation: from National Systems and "Mode 2" to a Triple Helix of university-industry-government relations. Research policy, 29(2), 109-123.

Etzkowitz, H., \& Leydesdorff, L. (1997) (eds), Universities in the Global Knowledge Economy: A Triple Helix of UniversityIndustry-Government Relations. London: Cassell Academic.

European Commission (2014). Regional Innovation Scoreboard 2014. Retrieved from http://bookshop.europa.eu/en/regional-innovation-scoreboard-2014-pbNBBC14001, referred on 11/12/2016.

European Commission (2015). Innovation Union Scoreboard 2015. Retrieved from https:/ / www.google.com/search?q=Innovation+Union + Scoreboard $+2015+\&$ \&ie $=u t f-8 \& o e=u t f-$ 8\&client=firefox-b , referred on 11/12/2016.

Fedirko, O. (2014). Key Trends and Problems of Regional Innovation Systems` Development in Poland and Ukraine central. European Business Review, 3(3), 38-45.

Hlaváček, P. (2013), Economic and Innovation Adaptability of Regions in the Czech Republic. Liberec Economic Forum 2013, Liberec, 194-203.

Hlaváček, P., Žambochová, M., \& Siviček, T. (2015). The influence of the institutions on entrepreneurship development: Public support and perception of entrepreneurship development in the Czech Republic. Amfiteatru Economic, 17(38), 408-421.

Hoppe, M. L., \& Winter, M. (2015, January). Measuring Innovation in Industry on a Trans-regional Comparison. In ISPIM Conference Proceedings (p. 1). The International Society for Professional Innovation Management (ISPIM), 1-16.

Klímová, V., \& Žítek, V. (2015). Innovation paradox in the Czech Republic: Economic theory and political reality. Politická ekonomie, 63(2), 147-166.

Kozun-Cieslak, G. (2017). Two faces of regional innovativeness - the evidence from visegrad group states. In: 19th International Colloquium on Regional Sciences, 325-332.

Nauwelaers, C., \& Reid, A. (1995). Methodologies for the evaluation of regional innovation potential. Scientometrics, 34(3), 497-511.

Nijkamp, P., Zwetsloot, F., \& van der Wal, S. (2010). Innovation and growth potentials of European regions: A metamulticriteria analysis. European Planning Studies, 18(4), 595-611.

OECD (2016). Oslo Manual: Guidelines for Collecting and Interpreting Innovation Data. Retrieved from http://www.oecd.org/sti/inno/oslomanualguidelinesforcollectingandinterpretinginnovationdata3rdedition.ht $\underline{m}$, referred on $12 / 12 / 2016$.

Oughton, C., Landabaso, M., \& Morgan, K. (2002). The regional innovation paradox: innovation policy and industrial policy. The Journal of Technology Transfer, 27(1), 97-110.

Pokorný, O. (2008). Analýza inovačního potenciálu krajo u České republiky. Technologické Centrum Akad. Věd ČR.

Ratajczak, W., \& Weltrowska-Jęch, J. (2008). Knowledge Regions - The EuropeanFuture. Modelling The European Future: Integrating The Old \& The New, 4, 461-472. 
Muscio, A., Reid, A., \& Rivera Leon, L. (2015). An empirical test of the regional innovation paradox: can smart specialisation overcome the paradox in Central and Eastern Europe?. Journal of Economic Policy Reform, 18(2), 153171.

Reichert, S. (2006). The Rise of Knowledge Regions: Emerging Opportunities and Challenges for Universities. European University Association. Retrieved from http://www.eua.be/uploads/media/The Rise of Knowledge Regions.pdf, referred on 15/12/2016.

Riche, M. (2010). Regional Innovation Governance. RegionalFocus, 2, European Commission, Regional Policy, Brussels, Retrieved from http://ec.europa.eu/regional policy/sources/docgener/focus/2010 02 innovation governance.pdf, referred on 11/12/2016.

Rodionov, D. G., Guzikova, L. A., \& Rudskaya, I. A. (2014). Innovation potential of regions as a factor of national economy competitiveness. Actual Problems of Economics, 158(8), 215-223.

Rodríguez-Pose, A., \& Di Cataldo, M. (2014). Quality of government and innovative performance in the regions of Europe. Journal of Economic Geography, 15(4), 673-706.

Romer, P. M. (1994). The origins of endogenous growth. The Journal of Economic Perspectives, 8(1), 3-22.

Streimikiene, D. (2014). The Impact of Research and Development for Business Innovations in Lithuania. Amfiteatru Economic, 16(37), 965-979.

Technological Agency of the Czech Republic (TACR) (2015). Projekt mapování inovační kapacity - INKA. Retrieved from https://www.tacr.cz/index.php/cz/novinky/586-projekt-mapovani-inovacni-kapacity-inka.html, referred on $11 / 12 / 2016$

Viturka, M., Žítek, V., Klímová, V., \& Tonev, P. (2011). Application of microeconomic and macroeconomic approach to the evaluating disparities in the regional development. Ekonomický casopis (Journal of Economics), 7(59), 655-668.
UNDP (2016).
Innovation
for
development.
Retrieved
from

http://www.undp.org/content/undp/en/home/ourwork/development-impact/innovation.html, referred on $181 / 12 / 2016$.

Zumbusch, K., \& Scherer, R. (2013). Mobilizing enterprises for regional innovation policies. how to assure an active involvement of located enterprises in regional development. Economics \& Sociology, 6(1), 13-27.

Zdražil, P., \& Applová, P. (2016). Growth disparities among regions of the Visegrad group countries: an evidence of their extent and nature. E+ M Ekonomie a Management, 19(2), 37-54 